\title{
The influence of extrovert and introvert personality types on the acceptance of virtual learning during the COVID-19
}

\section{pandemic: a survey [version 1; peer review: 2 approved with}

\section{reservations]}

\author{
Siti Rasyidah Sanudin (D1, Hawa Rahmat (D)1, Maizatul Azila Chee Din1, \\ Najihah Akeb-Urai
}

${ }^{1}$ Multimedia University (MMU), Melaka, Melaka, 76450, Malaysia

${ }^{2}$ International Islamic College, Malaysia, Kuala Lumpur, Malaysia

\author{
V1 First published: 24 Jan 2022, 11:87 \\ https://doi.org/10.12688/f1000research.73611.1 \\ Latest published: 24 Jan 2022, 11:87 \\ https://doi.org/10.12688/f1000research.73611.1
}

\section{Abstract}

Background: As a result of the COVID-19 pandemic, all courses taught in Malaysian schools and universities were conducted entirely virtually, after a movement control order was imposed in Malaysian on $18^{\text {th }}$ March 2020. According to the research by Offir et al., (2007), extroversion-introversion (E-I) personalities have been shown to influence students' involvement in class, their learning style and their understanding of the course materials. The purpose of this research was to explore how extrovert and introvert personality traits influence the acceptance of virtual learning amid the COVID-19 pandemic. Methods: A case study was conducted, focusing on a group of students taught by one of the researchers in our research team, HR. A total of 31 Diploma students (13 first year students and 18 second year students) taking Grooming and Professional Etiquette at Multimedia University, Malaysia (MMU) participated in the study. Open-ended questions were used to learn about the personality of each participant, as well as to provide a better understanding on how the opposing personas differs in their experiences with virtual learning.

Results: Our results showed that $54.83 \%$ (17) of the students were introverts, $29.03 \%$ (9) were extroverts, and $16.1 \%$ (5) were privatepublic-introvert-extroverts (PPIEs). The results for the acceptance level of virtual learning varied based on the different personality types. Results showed the extroverts expressed that the virtual learning experience was unpleasant, while the introverts and the PPIEs found virtual learning a useful and pleasant experience.

Conclusion: This study was mainly descriptive, with open-ended questions used to gain insight on how different personality types

\section{Open Peer Review \\ Approval Status ? ? \\ 12 \\ version 1 \\ 24Jan 2022

$?$
view \\ $?$ \\ view \\ 1. Nina B Eduljee, Saint Joseph's College of Maine, Standish, USA \\ 2. Azlina Mohd Khir, Universiti Putra Malaysia (UPM), Selangor, Malaysia}

Any reports and responses or comments on the article can be found at the end of the article. 
differ in their acceptance of fully virtual learning. In future studies, inferential analysis could be carried out to test the hypotheses and assumptions. Future studies could also compare and contrast both students and lecturers' acceptance of, and engagement in, online learning during the COVID-19 pandemic.

\section{Keywords}

personality, extroversion, introversion, Covid-19, virtual learning

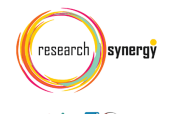

This article is included in the Research Synergy

singing

Foundation gateway.

Corresponding author: Hawa Rahmat (hawa.rahmat@mmu.edu.my)

Author roles: Sanudin SR: Conceptualization, Methodology, Writing - Original Draft Preparation, Writing - Review \& Editing; Rahmat H: Conceptualization, Formal Analysis, Funding Acquisition, Methodology, Project Administration, Writing - Original Draft Preparation, Writing - Review \& Editing; Chee Din MA: Conceptualization, Funding Acquisition, Writing - Review \& Editing; Akeb-Urai N: Formal Analysis, Funding Acquisition, Project Administration

Competing interests: No competing interests were disclosed.

Grant information: The author(s) declared that no grants were involved in supporting this work.

Copyright: $\odot 2022$ Sanudin SR et al. This is an open access article distributed under the terms of the Creative Commons Attribution License, which permits unrestricted use, distribution, and reproduction in any medium, provided the original work is properly cited.

How to cite this article: Sanudin SR, Rahmat H, Chee Din MA and Akeb-Urai N. The influence of extrovert and introvert personality types on the acceptance of virtual learning during the COVID-19 pandemic: a survey [version 1; peer review: 2 approved with reservations] F1000Research 2022, 11:87 https://doi.org/10.12688/f1000research.73611.1

First published: 24 Jan 2022, 11:87 https://doi.org/10.12688/f1000research.73611.1 


\section{Introduction}

One of the consequences of the COVID-19 pandemic is that many universities in Malaysia were forced to deliver classes entirely online, due to the movement control order (MCO) imposed in Malaysian on $18^{\text {th }}$ March 2020. ${ }^{1}$ Online classes mean students are not able to have personal or face-to-face contact with their teachers and other students and are not able to participate in discussions in the same way. Based on students respective personalities, these learning conditions may affect students' experience of virtual classes differently. Extroversion-introversion (E-I) variations have been shown to affect how students engage in class, their learning style and the way they process knowledge. ${ }^{2,3}$ Most studies have focused on students and teachers' engagement in online classes. ${ }^{4}$ However, very few studies have investigated how the differences in personality affect online learning, especially in relation to the acceptance and perception of virtual classes among students. As of March 2020 university classes are being conducted online, which presents a valuable opportunity to explore this question. The study's original goal was to investigate if there were any relationship between resilience and acceptance of virtual learning classes, across different personality types. However, owing to a lower number of responses from students than expected, the quantitative study was terminated, and instead, a qualitative analysis was conducted on various personalities types and students' acceptance of virtual classes. The study's research question then evolved into trying to understand whether personality types influence students' acceptance of virtual classes. Therefore, the objective of this paper is to explore how various personality types influence students' acceptance of virtual learning classes during the COVID-19 pandemic.

\section{Students' acceptance of virtual learning}

Research has shown that the psychological and emotional impact of the COVID-19 pandemic has been present from the very beginning. Roy et al. (2020), conducted a study in India using a questionnaire and non-probability snowball sampling technique; the study revealed that those who were concerned about the spread of COVID-19, had higher levels of anxiety. ${ }^{5}$ This leads us to ask how young adults are coping with the new experience of a fully virtual class load, in addition to anxiety around the pandemic and indicates the need to investigate students' level of acceptance of virtual learning and their feelings around such experiences.

In the province of Davao del Sur, southern Philippines, another study conducted in 2020 which focused on students' knowledge, attitude, anxiety, and coping mechanisms during the COVID-19 pandemic found that they were uninterested in the online-blended learning approach. ${ }^{6}$ In the study, 59.25\% (314 out of 530) of the students disagreed with the conduct of the online-blended learning approach. The study revealed that the primary reason for the disagreement was poor internet connection, which was reported by $72.29 \%$ (227 out of 314 ) of the students. However, even though in that study technical problems were the main cause, we believe personality factors could not be ignored since differences in personality may also affect students' acceptance and perception of online learning. ${ }^{2}$

\section{Extroverts and virtual learning}

Extroverts are described as having a diverse range of interests, being proactive in their work and relationships, are sociable, and have a strong sense of self-expression. According to research, extroverts enjoy events such as classroom discussions, group projects, and opportunities to engage with the teachers, and brainstorming or discussing ideas. ${ }^{3,7}$

\section{Introverts and virtual learning}

Introverts tend to engage in activities such as listening and reflection before responding to questions from the teachers and prefer writing as a means of communication and contemplation as a means of working out ideas. ${ }^{3}$ Generally, this is also their preferred way of learning and they perform best when given time to reflect and process before participating in classroom activities, while extroverts need a high degree of stimulus to stay engaged. Research has reported that various strategies have been used by students to cope with learning during the pandemic such as reminding themselves of the positive benefits it has in limiting the spread of the virus and protecting them from exposure. ${ }^{6}$ Respondents who avoided thinking about the pandemic or those struggling to cope, had significantly greater anxiety and depression. ${ }^{6}$

\section{Private-public-introvert-extroverts (PPIEs) and virtual learning}

A PPIE individual is in-between an extrovert and introvert. PPIEs are also known as ambiverts. ${ }^{8}$ This type of personality will become agile, active, and energetic when they are within their small circle of friends or when they are with their own family. ${ }^{9}$ However, when they are with a stranger, they are quiet and seem less interested to start a conversation. ${ }^{10}$ Zholudeva et al. (2021) also found that ambiverts or PPIEs had a greater degree of preparedness for a future career, than extroverts and introverts, when looking at the readiness of students for professional careers. ${ }^{11}$

\section{Methods}

Ethics

Written informed consent was obtained from the respondents, for both involvement in the study and use of data and students could also withdraw from participating in the survey. Ethical approval was granted by Research 
Ethics Committee of the Technology Transfer Office, Multimedia University, Malaysia. Ethical approval number: EA0712021.

We conducted a case study on a group of students $(n=31)$ in one of the classes taught by the second author in the research team, HR. The survey questionnaires were administered to the students via Google Forms during a virtual class ${ }^{12}$ in Grooming and Professional Etiquette, at Multimedia University, Malaysia on $27^{\text {th }}$ May 2021. This subject is offered for students in their first and second year of their studies. A six item resilience questionnaire was adapted from the Brief Resilience Scale (BRS $)^{13}$ and included in the survey. A five-item Likert scale, ranging from strongly disagree to strongly agree was also incorporated; including statements aimed to establish students' resilience, such as "I tend to bounce back quickly after hard times". Data collected included information about the demographic background of the students such as gender, religion, ethnicity, year of study, and personality traits. The students were given a link to a personality test website specifically designed for identifying their personality traits. ${ }^{14}$ The students took the test online and results were automatically generated. There are three types of personality generated: extroverts, introverts, and PPIEs. Then students were encouraged to ask questions regarding the survey, if they did not understand any of the parts. Finally, the students were instructed to submit the Google form once they have completed the survey. The analysis of students' acceptance of online learning was carried out based on the open-ended questions which were asked, to gain insight on the students' experience, acceptance and perception of the virtual learning experience. The questions were as follows (see Extended data for a copy of the survey $^{12}$ ):

- Do you like the classes to be conducted $100 \%$ online? Why and why not?

- Do you prefer $100 \%$ online classes or would you prefer a certain percentage of classes be face to face? Why and why not?

- When the COVID-19 pandemic is over, do you still want online classes for this subject?

\section{Results}

The responses from the students did not meet the sample size recommendation by Krejcie and Morgan. ${ }^{15}$ Thus, due to a lower than the projected number of responses from students, the resilience questions are excluded in the analysis, and instead, a qualitative analysis on various personality types and students' acceptance of virtual classrooms was done. A total of 31 students participated in the study. The demographic background of the student participants is shown in Table 1.

The findings obtained from this study revealed interesting differences between extrovert and introvert students in relation to their acceptance of virtual learning. Table 2 showed the results of personality types and the acceptance of virtual

Table 1. Demographic background of the participants.

\begin{tabular}{|l|l|l|}
\hline & Frequency & Percentage \\
\hline Gender & 15 & 48.38 \\
\hline Male & 16 & 51.61 \\
\hline Female & & \\
\hline Ethnicity & 4 & 12.9 \\
\hline Malay & 23 & 74.19 \\
\hline Chinese & 4 & 12.9 \\
\hline Indian & & \\
\hline Religion & 4 & 12.9 \\
\hline Islam & 17 & 54.84 \\
\hline Buddhism & 3 & 9.68 \\
\hline Hinduism & 7 & 22.58 \\
\hline Christian & & 41.94 \\
\hline Year of study & 13 & 58.06 \\
\hline First year & 18 & \\
\hline Second year & & \\
\hline
\end{tabular}


Table 2. Personality types and acceptance of virtual learning.

\begin{tabular}{|l|l|l|l|l|}
\hline Personality types & \multicolumn{2}{|l|}{$\begin{array}{l}\text { Acceptance on virtual learning during } \\
\text { pandemic }\end{array}$} & No & \multicolumn{2}{l|}{$\begin{array}{l}\text { Acceptance on virtual learning after } \\
\text { pandemic }\end{array}$} \\
\hline & Yes & $4(33 \%)$ & Yes & No \\
\hline Introverts 17 (55\%) & $11(58 \%)$ & $10(56 \%)$ & $5(38 \%)$ \\
\hline Extroverts 9(29\%) & $6(32 \%)$ & $5(42 \%)$ & $6(33 \%)$ & $5(38 \%)$ \\
\hline PPIEs 16 (16\%) & $2(10 \%)$ & $3(25 \%)$ & $2(11 \%)$ & $3(24 \%)$ \\
\hline Total 31 (100\%) & $19(61 \%)$ & $12(39 \%)$ & $18(58 \%)$ & $13(42 \%)$ \\
\hline
\end{tabular}

learning. Based on the test that the students took, 55\% (17) of the students were categorised as introverts, $29 \%$ (9) were extroverts, and 16\% (5) met the private-public-introvert-extrovert personality type. About 61\% (19) students positively accepted virtual learning and 39\% (12) students did not enjoy virtual learning during the pandemic. From the 19 students who positively accepted virtual learning during the pandemic, $58 \%$ (11) of them were introverts, $32 \%$ (6) extroverts, and $10 \%$ (2) PPIEs.

The results reveal that the introverts seemed happy attending fully virtual classes and preferred staying at home rather than meeting people. This is consistent with the characteristics of introverts; being people who do not like to be around large groups and can tend to avoid public places or crowded events. ${ }^{10}$ Introverts also prefer to communicate through writing.

Compared to extroverts, introverts perform best when given time to reflect and process before participating in classroom activities. ${ }^{7}$ The results of our study confirmed the findings of research conducted by Offir et al., (2007), in which extroverts were found to dislike virtual classes. ${ }^{2}$ For the extroverts in our study, having a certain percentage of classes conducted online is acceptable; however, they could not completely focus if they had to attend fully virtual classes. They preferred meeting people, talking to friends, and consulting their lecturers face-to-face. This was evidently expressed by one of the extrovert first-year female students (respondent no. 17), who mentioned in the open-ended question that "I must see people, meet people, talk to real people. I need a high degree of stimulus to stay involved". ${ }^{12}$

We found that PPIE students did not like virtual classes, but that they are quite tolerant of such classes because of the situation created by the pandemic. Nevertheless, they claimed that they have to contact friends and lecturers after classes, for further help to understand the topic being studied. PPIE students reported that the virtual classes are satisfying enough if they have at least one or two classes where they are able to meet up in person with other students or teachers. This is in-keeping with the traits of PPIEs, whereby being able to meet and talk to people in person every now and then, is sufficient.

Extroverts are described by C. G. Jung (1971), who is a key figure in the study of personalities, as being oriented primarily toward the outside world, and as such, they prefer to focus their observation and judgment on people and objects. Introverts, on the other hand, are more focused on the inner world and thus, prefer to focus their observation and judgment on thoughts and ideas. ${ }^{16}$ As such, in any online class, there will likely be introvert students paying close attention and focusing on what the lecturer is trying to convey and working hard to complete all the work assigned to them. The extroverts might find being confined to one place, within which they are not able express their concern to the lecturer or fellow students, annoying and stressful. ${ }^{10}$ The findings of our study suggest that online learning is valuable, but a certain percentage of face-to-face activities are needed for a better student-teacher and student-peer engagement. Furthermore, according to Lestari et al. (2013), introvert and extrovert students have different learning styles; introvert students preferring to study alone while extroverts prefer to study in groups. ${ }^{7}$

\section{Conclusion}

The findings indicate that the students are aware of and understand the need for online learning during the COVID-19 pandemic. They have no choice but to follow the new norm of learning in the current situation. For now, online learning is the only way that teacher-student interaction can be conducted in some countries, and one must adapt to the changing environment.

The results of the open-ended questions help researchers better understand how extroverts, introverts, and PPIE students perceive and embrace completely virtual learning programs. Even though the introverts indicated that virtual classes were ok for them, they stated that they still needed to see people in person to keep them "alive" and "intact". ${ }^{12}$ The urge to meet others, such as friends, classmates, and lecturers, is for study objectives rather than social purposes for introverts. 
Extroverts must interact with actual people in order to communicate, be heard and listen and love sharing their lives with others; not just for academic objectives.

Arguably, online learning, in a more structured way, could be the future of our teaching and learning. Perhaps, what we are facing now is just the beginning of a more complicated but perhaps stimulating future of education. However, the study cannot be generalised to all Malaysian students since it was only a case study with a small group of students in a Grooming and Professional Etiquette class at Multimedia University. Further research is therefore required to replicate this study on a larger scale, to aid better generalisability. More research is suggested to understand further the differences in personality and how it affects perceptions of online learning, with the hope that such research would be able to inform and improve teaching and learning methods in the future.

\section{Data availability}

Underlying data

DANS: The influence of extroversion and introversion personality types on the acceptance of virtual learning during the COVID-19 pandemic, https://doi.org/10.17026/dans-2zc-x4u2. ${ }^{12}$

This project contains the following underlying data:

\section{- DATASET_PAPER ONLINE LEARNING AND PERSONALITY.csv}

\section{Extended data}

DANS: The influence of extroversion and introversion personality types on the acceptance of virtual learning during the COVID-19 pandemic, https://doi.org/10.17026/dans-2zc-x4u2. ${ }^{12}$

This project contains the following extended data:

- F1000_questionnaire_GROOMING CLASS ACCEPTANCE ON VIRTUAL CLASSES - Google Forms.pdf

Data are available under the terms of the Creative Commons Zero "No rights reserved" data waiver (CC0 1.0 Public domain dedication).

\section{Acknowledgments}

Thank you to the students in Grooming and Professional Etiquette class at Multimedia University, Malaysia that participated in the study.

\section{References}

1. Tang K: Movement control as an effective measure against Covid-19 spread in Malaysia: an overview. Zeitschrift fur Gesundheitswissenschaften = Journal of Public Health. 2020; 1-4. Advance online publication.

Publisher Full Text

2. Offir B, Bezalel R, Barth I: Introverts, extroverts, and achievement in a distance learning environment. Am. J. Dist. Educ. 2007; 21(1): 3-19.

Publisher Full Text

3. Murphy L, Eduljee NB, Croteau K, et al.: Extraversion and introversion personality type and preferred teaching and classroom participation: A pilot study. J. Psychosoc. Res. 2017; 12(2): 437-450.

4. Aguilera-Hermida AP, Quiroga-Garza A, Gómez-Mendoza S, et al.: Comparison of students' use and acceptance of emergency online learning due to COVID-19 in the USA, Mexico, Peru, and Turkey. Educ. Inf. Technol. 2021; 26: 6823-6845. Publisher Full Text

5. Roy D, Tripathy S, Kar SK, et al.: Study of knowledge, attitude, anxiety \& perceived mental healthcare need in Indian population during COVID-19 pandemic. Asian J. Psychiatr. 2020; 51: 102083 . 2020; 51: 102083.
PubMed Abstract | Publisher Full Text
6. Baloran ET: Knowledge, Attitudes, Anxiety, and Coping Strategies of Students during COVID-19 Pandemic. J. LoSS Trauma. 2020; 25: 635-642. Publisher Full Text

7. Lestari A, Sada C, Suhartono L: Analysis On the Relationship of Extrovert; Introvert Personality and Students Speaking Performance. Jurnal Pendidikan dan Pembelajaran Khatulistiwa. 2013; 4(3).

8. Luong V, Shields C, Petrie A, et al.: Does Personality Matter? Perceptions and Experiences of Introverts and Extraverts as General Surgeons. Teach. Learn. Med. 2021: 1-11. PubMed Abstract | Publisher Full Text

9. Downs GH: An exploration of the relationship between personality type and satisfaction with online learning environments. 2019 Portland International Conference on Management of Engineering and Technology (PICMET). 2019, August; (pp. 1-4). IEEE.

10. Bishop-Clark C, Dietz-Uhler B, Fisher A: The effects of personality type on web-based distance learning. J. Educ. Technol. Syst. 2007; 35(4): 491-506. Publisher Full Text

11. Zholudeva S, Zhukova R, Naumenko M: Readiness for the Profession of Students With Different Psychotypes in a Digital 
Educational Environment. E3S Web of Conferences 2021; (Vol. 258). EDP Sciences.

12. Sanudin SR: The influence of extroversion and introversion personality types on the acceptance of virtual learning during the COVID-19 pandemic. DANS. 2021

Publisher Full Text

13. Smith BW, Dalen J, Wiggins K, et al.: The brief resilience scale: assessing the ability to bounce back. Int. J. Behav. Med. 2008; 15(3): 194-200.

PubMed Abstract | Publisher Full Text
14. Bishop-Clark C, Dietz-Uhler B, Fisher A: Test: Are you an introvert or an extrovert?. 2018. Retrieved on 30 May 2021. Reference Source

15. Krejcie RV, Morgan DW: Determining sample size for research activities. Educ. Psychol. Meas. 1970; 30(3): 607-610. Publisher Full Text

16. Jung CG: Psychological types Trans. Baynes HG, Hull RFC, editors. Princeton, NJ: Princeton University Press; 1971. (Orig. pub. 1921.) 


\section{Open Peer Review}

\section{Current Peer Review Status: ? ?}

\section{Version 1}

Reviewer Report 23 February 2022

https://doi.org/10.5256/f1000research.77274.r120905

(c) 2022 Mohd Khir A. This is an open access peer review report distributed under the terms of the Creative Commons Attribution License, which permits unrestricted use, distribution, and reproduction in any medium, provided the original work is properly cited.

\section{Azlina Mohd Khir}

Department of Social and Development Sciences, Faculty of Human Ecology, Universiti Putra Malaysia (UPM), Selangor, Malaysia

Overall, the presentation of this article is clear, readable and interesting. However, some suggestions could be taken into consideration.

1. The abstract is well explained. However, citations should not be used in the abstract.

2. The introduction should explain in-depth the virtual learning itself, including its conceptual definition (with citations).

3. The literature review is well explained. However, it is suggested to add more citations to make the literature review more robust.

4. Methods: Please explain the population and sampling technique used in the study. How was the data analyzed? What techniques did you use to analyze the quantitative and qualitative data? Please explain in detail.

5. Results:

You need to re-check the data in Table 2.

There is a typo for the total number of PPIE respondents. The correct number is 5, not 16 (equivalent to $16 \%$ ).

- The total number of Introverts is 17, if 11 respondents answer 'Yes' to Acceptance on virtual learning during the pandemic, so the number who answered 'No' will be 6 . Why have you stated it is 4 ?

Also for Extroverts, the total number of Extroverts is 9. If 6 respondents answer 'Yes' for the Acceptance of virtual learning during the pandemic, why have are you stated 5 in the 'No' column, and not 3 ?

Also, re-check the frequency for Introverts and Extroverts who answer 'No' to the Acceptance of virtual learning after the pandemic. 
How can Table 2 describe which personality type is more accepted in virtual learning? Highly suggested to add the results from the Acceptance on Remote Learning scale.

How do you analyze the open-ended questions? It is suggested to explain well in this section, e.g. based on the themes, or some statements by the respondents that can be added to the narrative.

6. The conclusion is well explained.

Is the work clearly and accurately presented and does it cite the current literature? Yes

Is the study design appropriate and is the work technically sound?

Yes

Are sufficient details of methods and analysis provided to allow replication by others? Partly

If applicable, is the statistical analysis and its interpretation appropriate? Partly

Are all the source data underlying the results available to ensure full reproducibility? Yes

Are the conclusions drawn adequately supported by the results? Yes

Competing Interests: No competing interests were disclosed.

Reviewer Expertise: Social Psychology

I confirm that I have read this submission and believe that I have an appropriate level of expertise to confirm that it is of an acceptable scientific standard, however I have significant reservations, as outlined above.

Reviewer Report 11 February 2022

https://doi.org/10.5256/f1000research.77274.r120901

(C) 2022 Eduljee N. This is an open access peer review report distributed under the terms of the Creative Commons Attribution License, which permits unrestricted use, distribution, and reproduction in any medium, provided the original work is properly cited.

Nina B Eduljee

Saint Joseph's College of Maine, Standish, ME, USA

The study was interesting and the authors recognized the limitations of the study $(n=31)$, and quickly pivoted to conducting a descriptive study. It would have been interesting to see what $\%$ of 
males and females were introverts and extroverts. That data can be added easily.

Does this journal have a word limit on articles? A couple of other studies (or citations if there is a word limit) could be added to make to the literature review more robust.

The authors state that they excluded the resilience questions due to not meeting sample size recommendations. Did the authors not examine the 9 questions on acceptance of remote learning (maybe mean/SD could be presented)? That can also be added as part of the results easily.

The open-ended questions were interesting but I was not able to access the responses, so had to go with the narrative the authors provided. Did they look for themes with the data? That could have been included with the results or some statements by the students could have been added in the narrative.

The conclusion addressed the key issues of the generalizability of the study. It would be very interesting to replicate on a larger scale to see if the results hold.

Overall, an interesting study that can be made even more robust with minor changes and additions.

Is the work clearly and accurately presented and does it cite the current literature? Yes

Is the study design appropriate and is the work technically sound? Yes

Are sufficient details of methods and analysis provided to allow replication by others? Partly

If applicable, is the statistical analysis and its interpretation appropriate?

Yes

Are all the source data underlying the results available to ensure full reproducibility? Yes

Are the conclusions drawn adequately supported by the results? Yes

Competing Interests: No competing interests were disclosed.

Reviewer Expertise: Educational Psychology.

I confirm that I have read this submission and believe that I have an appropriate level of expertise to confirm that it is of an acceptable scientific standard, however I have significant reservations, as outlined above. 
The benefits of publishing with F1000Research:

- Your article is published within days, with no editorial bias

- You can publish traditional articles, null/negative results, case reports, data notes and more

- The peer review process is transparent and collaborative

- Your article is indexed in PubMed after passing peer review

- Dedicated customer support at every stage

For pre-submission enquiries, contact research@f1000.com 